\title{
Introducing the New Journal Critical Romani Studies
}

\author{
Maria Bogdan \\ bogdanmarcsi@gmail.com \\ Media Theorist and Journalist, Visiting Researcher at CEU \\ Romani Studies Program \\ ORCID: http://orcid.org/0000-0003-1146-3249
}

Maria Bogdan's main research interest is related to media representation and modern forms of racism. For her $\mathrm{PhD}$ thesis she has been focusing on the media representation of Roma in Hungary. She is a Fulbright Alumna and has done part of her $\mathrm{PhD}$ research at Columbia University in the City of New York. She was a research fellow at the Hungarian Academy of Sciences (2014-2017) and was an assistant lecturer at the University of Pécs (2006-2013). As a journalist, she worked at different television and radio stations and newspapers across in Hungary. Currently Bogdan is a visiting researcher fellow at CEU Romani Studies Program.

\section{Jekatyerina Dunajeva \\ katyadunajeva@gmail.com}

Assistant Professor at the Institute of International Studies and Political Science, Pázmány Péter Catholic University

ORCID: https://orcid.org/0000-0003-1826-6731

Dr. Jekatyerina Dunajeva received her $\mathrm{PhD}$ at the University of Oregon. In her dissertation, she examined how schooling affected Roma identity formation over time in Hungary and Russia. Dr. Dunajeva's research has been published in several edited volumes and peer-reviewed journals. Her fields of research are Roma, political and ethnic identity, youth politics, and state- and nation-building. In addition to teaching at Pázmány Péter Catholic University, Dr. Dunajeva collaborates with international research groups, working as a consultant and political analyst.

\section{Tímea Junghaus}

timea.junghaus@gmail.com

Executive Director of the European Roma Institute for Arts and Culture

ORCID: https://orcid.org/0000-0001-9545-1493

Tímea Junghaus is an art historian and contemporary art curator. She has been the Executive Director of the Berlin-based European Roma Institute for Arts and Culture since its opening in 2017. Previously, Junghaus was a Research Fellow of the Working Group for Critical Theories at the Institute for Art History, Hungarian Academy of Sciences (2010-2017). She has researched and published extensively on the conjunctions of modern and contemporary art with critical theory, with particular reference to issues of cultural difference, colonialism, and minority representation. She is completing her PhD studies in Cultural Theory at Eötvös Lóránd University, Budapest.

\section{Angéla Kóczé \\ koczea@ceu.edu}

Assistant Professor of Romani Studies and Academic Director of the Roma Graduate Preparation Program at Central European University ORCID https://orcid.org/0000-0001-7077-1642

Angéla Kóczé is Assistant Professor of Romani Studies and Academic Director of the Roma Graduate Preparation Program at Central European University. In 2013-14, she was a Visiting Assistant Professor in the Department of Sociology and Women's, Gender, and Sexuality Studies Program at Wake Forest University in Winston-Salem, North Carolina. She was the principal investigator of a research project (2013-16) titled Institutionalization of Romani Politics After 1989 in Hungary, funded by the Hungarian Social Research Fund. Her research focuses on the intersections between gender, ethnicity and class as well as the social and legal inequalities faced by the Roma in various European countries. She has published several peer-reviewed academic articles and book chapters with various international presses including Palgrave Macmillan, Ashgate, and Central European University Press, as well as several thematic policy papers related to social inclusion, gender equality, social justice, and civil society. She currently is preparing a monograph on the political activism and social struggles of Romani women in post-socialist Europe, as well as an edited volume that takes stock of the contemporary situation and identity struggle of Europe's Romani minority. In 2013, the Woodrow Wilson International Center for Scholars in Washington, D.C. honored Kóczé with the Ion Ratiu Democracy Award for her interdisciplinary research approach, which combines community engagement and policymaking with in-depth participatory research on the situation of the Roma.

\section{Iulius Rostas \\ rostasi@ceu.edu}

Chair of Romani Studies and Assistant Professor

Central European University

ORCID https://orcid.org/0000-0001-9646-5619

Dr. Iulius Rostas is the Chair of Romani Studies/Assistant Professor at Central European University in Budapest. He was an Affiliated Fellow with the Institute for Advanced Studies at CEU, Senior Fellow with the Open Society Foundations Roma Initiatives Office, and a Visiting Lecturer at Corvinus University of Budapest. Dr. Rostas is the editor of Ten Years After: A History of Roma School Desegregation in Central and Eastern Europe (CEU Press, 2012), and in 2011 he published Social Inclusion or Exclusion: The Rights of Persons Living with HIV in Moldova (Cartier Publishing). His upcoming book, Ethnicity, Power and Inclusion: Why Policies Towards Roma in Europe Are Failing, will be published by CEU Press in 2018.

\section{Márton Rövid \\ marton.rovid@gmail.com}

Post-doctoral Fellow, Central European University

ORCID: https://orcid.org/0000-0002-5072-4547

Márton Rövid is an activist-scholar, a dedicated teacher, and an experienced policy analyst. He holds a $\mathrm{PhD}$ in political science from Central European University. Currently, he is a Post-Doctoral Fellow in the Department of Economics and Business at CEU, and a teacher at the Jesuit Roma College in Hungary. His most recent publication is "Roma and the Politics of Double Discourse in Contemporary Europe" (with Angéla Kóczé, Identities, 2017). Between 2012 and 2015, as a research and advocacy officer at the Decade of Roma Inclusion Secretariat, he coordinated the monitoring of Roma policies in 16 countries. His research interests include: theories of cosmopolitan democracy, global civil society, transnational social movements, and racialization in post-communist contexts.

\section{Marek Szilvasi \\ szilmar@gmail.com}

Program Officer, Public Health Program, Open Society Foundations OCRID http://orcid.org/0000-0002-0072-9921

Dr. Marek Szilvasi works for the Public Health Program of the Open Society Foundations, where he focuses on health law and equality. He also teaches at the Institute of Politics and International Studies of the Eötvös Lóránd University in Budapest. Dr. Szilvasi holds a PhD in Sociology from the University of Aberdeen. In 2017 he was awarded the Martin Alexandersson Research Scholarship of the Raoul Wallenberg Institute and the CAS-SEE/University of Rijeka Post-doctoral Fellowship. 


\section{The Origins of the Journal}

Critical Romani Studies is the brainchild of a group of young activist-scholars from Budapest who saw a need to center Romani voices in the production of scholarship about Roma. The founding editors of the Journal have diverse personal and academic backgrounds. Each of us conducted our doctoral studies on topics related to the oppression and emancipation of Roma in diverse disciplines such as art history, media studies, political anthropology, political science, and sociology. We have all been involved in civic activism and the advocacy activities of various NGOs such as the Decade of Roma Inclusion Secretariat Foundation, the European Roma Cultural Foundation, the European Roma Rights Centre, the Open Society Foundations, and the Roma Education Fund. We believe that these organizations play an important role in the struggle for Romani emancipation; however, we wanted to go beyond advocacy and to create venues in which scholars and activists could reflect critically on key questions of this struggle.

Beginning in 2011, a group of us started to organize discussions in various cafés and pubs in the eighth district of Budapest. We created the informal Roma and Research Empowerment Network to bring together Roma and non-Roma researchers, activists, and concerned citizens who are committed to the social justice and equality of Roma. With invited speakers, we discussed diverse topics such as the expulsion of Roma from France, Roma school segregation, a local empowerment project in a Hungarian village, the situation of Roma in the Baltic states, the place of Beash identity in the Romani movement, early marriages, the anti-Roma marches in Czech cities, and post-colonial approaches to Romani Studies.

In addition to the informal discussions, we organized three conferences at Corvinus University Budapest: "Working Together for Roma Inclusion in the School and Community" (2012); "Roma Participation, Empowerment, and Emancipation" (2013); and "Roma Participation in Knowledge Production and Policy Making" (2014). ${ }^{[1]}$ We held a number of workshops in conjunction with these conferences in a community center in the so-called "Roma ghetto" of Budapest, highlighting the importance of knowledge production outside academia.

The workshops held in 2014 focused on transforming the Romani movement, building coalitions with the feminist and LGBTQ rights movements as well as with trade unions; knowledge production and Roma representation; and the plan of setting up a pan-European Romani cultural institute. The organizers invited the participants to publish their ideas in a special issue of Roma Rights, the Journal of the European Roma Rights Centre, titled "Nothing About Us Without Us? Roma Participation in Policy Making and Knowledge Production". ${ }^{[2]}$

1. The "core members" of the network have changed throughout the years. The following persons organized the conferences: in 2012, Iulius Rostas and Andrew Ryder; in 2013, Crina Marina Morteanu, Iulius Rostas, Márton Rövid, Andrew Ryder, Marius Taba, Timofey Agarin; in 2014, Maria Bogdan, Jekatyerina Dunajeva, Tímea Junghaus, Iulius Rostas, Márton Rövid, Andrew Ryder, Marek Szilvasi, Marius Taba. Angéla Kóczé contributed to the journal issue published after the 2014 conference. You can find more information on the Roma Research and Empowerment Network at: https://romaempowerment.wordpress.com

2. http://www.errc.org/roma-rights-journal/roma-rights-2-2015-nothing-about-us-without-us-roma-participation-in-policymaking-and-knowledge-production/4433 
Several papers in this publication challenge the hegemonic academic narratives on Roma. In their respective essays, Anna Mirga-Kruszelnicka and Angéla Kóczé interrogate the legacies of knowledge production in the field of Romani Studies. Although a handful of established scholars felt compelled to react to these articles - the authors were called "NGO scientists" and the publication "a campaigning magazine" - this special issue has become an important reference for subsequent critical studies on knowledge production on Roma. Romani activist-scholars who serve as teachers, researchers, or scholars under the purview of academic governance, share the plight of other racialized scholars who are unconsciously perceived as "incompetent" ${ }^{[3]}$ and who are accused of "dilut[ing] academic rigorousness". These are unmeasurable "standards" created by mainly white upper-middle-class scholars (Gutiérrez et al., 2012). The position of any colored, racialized person is repeatedly undermined as a result of persistent structural inequality and the myths of meritocracy.

It thus became clear to us that a new academic journal was needed, specifically in order to create a platform for scholars seeking to embrace standpoint epistemologies and critical social theories in their research and writing about issues faced by Romani people. With its strong history of dedication to socially and morally responsible intellectual inquiry, Central European University (CEU) agreed to host and publish this new journal. CEU has been offering Roma-related courses and has supported Roma-related research since the 1990s. In 2004, the University launched the Roma Graduate Preparation Program, which sought to prepare Romani BA graduates for MA studies in English. In 2015, Ethel Brooks organized the summer school "Performing Romani Identities: Strategy and Critique" that represented a critical shift from earlier similar summer courses held at CEU. In 2016, Iulius Rostas was appointed Chair of Romani Studies and Angéla Kóczé was recruited as an assistant professor of Romani Studies. The new journal is being published by the Romani Studies Program at Central European University within the framework of CEU's Roma in European Society initiative.

\section{Why a New Journal?}

We are launching this journal to provide a forum for activist-scholars to critically examine racial oppressions, different forms of exclusion, inequalities, and the human rights abuses of Roma. Without compromising academic standards of evidence collection and analysis, the Journal seeks to create a platform to critically engage with academic knowledge production, and generate critical academic and policy knowledge targeting - amongst others - scholars, activists, and policymakers. We see scholarly expertise as a tool, rather than an end, for critical analysis of social phenomena affecting Roma, and the fight for social justice writ large.

We acknowledge the importance of including the voice of Roma in knowledge production, and we aim to promote "talking back" (hooks, 1989). ${ }^{[4]}$ Considering the history of oppression, structural inequalities,

3. See in: Muhs, G. G., Niemann, Y. F., González, C. G., and Harris, A. P. (eds.) (2012). Presumed Incompetent: The Intersections of Race and Class for Women in Academia. Logan: Utah State University Press.

4. hooks, b. (1989) Talking Back: Thinking Feminist, Thinking Black. Boston: South End Press. 
and persistent exclusion of Roma from various social realms, including scholarly endeavors, the language of academic knowledge concerning Roma is that of the dominant, non-Roma group. Therefore, it is imperative to include "liberatory voices" that will "take us away from the boundaries of domination", as these very voices constitute a site of resistance to the exclusionary practices that still exist in academia (hooks, 1989: 28-29).

We consider scholarship on Romani and other populations that fails to incorporate the voice of the "target population" to be unethical, abusive, offensive, and methodologically flawed. The Journal aims to expose the different gendered, racialized positions and lived experiences of Roma as a basis for theorizing various forms of structural exclusion. We believe that this field of research should not be appropriated by a benevolent self-referencing group of white scholars; rather we promote an open, interand transdisciplinary movement that integrates diverse and heterogeneous voices.

The Journal aims to promote researchers who reflect critically on their own position and responsibility, but who at the same time remain committed to undertaking research of high academic standards. We are particularly interested in publishing results of participatory action research in which Romani "local informants" have been involved in all phases of the research and who are concerned not only with producing pure academic knowledge but also transforming local power relations.

We believe that that the separation between the advancement of science and the advancement of practice is not only illusory, but also detrimental to "target populations". Even if the research does not focus on local phenomena and therefore does not engage directly with local Romani inhabitants (for instance, studying so-called Roma inclusion policies), the researcher may still support and empower Romani voices that challenge (in this example) the hegemonic policy mechanisms being studied. The strict separation between activism and science is often promoted by well-established white, male "Western" scholars who are reluctant to reflect on their own privilege and are interested in maintaining the exclusion of oppressed voices from academia. We believe that scientific knowledge can be produced by respecting academic rigor, using multiple research methods while also supporting the struggles of oppressed communities. The research design and the product reflect the position of the scientist and are informed by the researcher's values. The Journal seeks to promote research on various forms of social oppression openly standing up against injustice while promoting diversity, equality, defense of human rights, respect for Roma communities, open dialogue, and respect for dissent.

The Journal seeks to transform not only Romani Studies but also account for past injustices that have suppressed the voices of racialized minorities. Borrowing hooks' terminology, the Journal strives to contribute to an "education of critical consciousness", which in turn may transform the culture of domination in academia and beyond. Academia and knowledge production thus become prime sites for acknowledging and challenging exclusionary practices and marginalization, including racism and sexism; and for transforming those discourses by including the voices of the oppressed.

Such a critical scholarly attitude creates not only new discourses, but also provides new ways for the academic world to reflect on and bring about changes in our societies. In other words, critical approaches in Romarelated research not only challenge the concepts and perspectives of the Humanities and Social Sciences, but 
they also transform the means and language of social activism. In particular, the Journal aims to contribute to the diverse movement for Romani self-determination and emancipation. This emerging movement comprises activists, artists, experts, politicians, scholars, and students, as well as non-governmental and intergovernmental organizations, and various national and local bodies. The Journal seeks to provide a forum for in-depth discussion of the key questions, challenges, and dilemmas of the Romani movement.

The proliferation of equality and social inclusion policies indicate an increasing recognition of discrimination and violence against Roma. Various (local, national, international) organizations, however, fail to tackle the enduring injustices Roma face even as they claim their commitment to "Roma inclusion", "antidiscrimination", "the rights of minorities", "protecting fundamental rights", and so forth. These so-called Roma integration strategies have offered nothing more than short-term depoliticized solutions for a long history of psychological and material subjugation, structural oppression, and racial violence. Despite twenty years of European Roma inclusion policymaking, in some areas such as health and housing policy, Roma throughout Europe continue to experience the same level of exclusion and discrimination as in the past decades. We aim to create a platform to critically engage with projects, programs, and policies targeting Roma. We wish to develop a public sphere where the desirability, efficiency, and legitimacy of pro-Roma initiatives and institutions can be debated.

We believe that engagement with racism and racialization cannot be detached from the economicpolitical transformation of the last three to four decades, which is often described as the expansion of "neoliberalism". In response, the Journal seeks to dismantle the walls of the Romani Studies "ghetto". The narrow focus on "Roma inclusion" has diverted attention from questions of social justice, welfare, democracy, and diversity. To this end, the Journal actively solicits contributions from anti-racist, feminist, LGBTQ, and leftist scholars.

\section{About the New Journal}

The Journal we are introducing here - Critical Romani Studies - is an international, interdisciplinary, peer-reviewed Journal that provides a forum for scholars and activists to critically examine racial oppressions, different forms of exclusion, inequalities, and human rights abuses of Roma, as well as issues of identity, mobilization, and resistance. The Journal especially welcomes the cross-fertilization of Romani studies with the fields of critical race studies, gender and sexuality studies, critical policy studies, diaspora studies, colonial studies, postcolonial studies, and studies of decolonization.

Published by the Romani Studies Program at CEU, the Journal meets the strict academic standards of mainstream academic publishers that dominate the industry while avoiding their exploitative practices. The Journal considers only previously unpublished manuscripts which present original, high-quality research. Editorial screening and double-blind peer review ensure the high academic standards of every article published by the Journal. The Editorial Board consists of prominent critical scholars who inspired the founding of the Journal. In contrast to many academic journals, the editorial board of Critical Romani Studies does more than play a symbolic role. Board members advise on the direction and policy of the Journal, give feedback on articles and issues, and recommend topics, potential authors, and reviewers. 
We believe that academic publishing has become a commodified and exploitative industry wherein only a limited number of privileged scholars and activists have access to international academic journals of high caliber. Fighting against and in an effort to transform these practices, we are joining the open access movement; all articles of Critical Romani Studies are available free of charge. Furthermore, the Journal remunerates authors, editors, and reviewers for their intellectual work and contributions.

Historically, Romani scholars have encountered significant barriers in engaging with academic knowledge production. The Journal actively solicits the emergence of critical Romani scholars through conference invitations, personal mentoring, organizing writing retreats, and commissioning shorter pieces such as blog posts or book reviews. We strive to provide all necessary assistance for such scholars to successfully participate in knowledge production.

We call for unpublished papers annually. The Romani Studies Program at Central European University organizes annual conferences for scholars embracing critical approaches and methods. Selected participants present their draft papers at these conferences and receive thorough feedback from a discussant and the other invited scholars. We recommend that authors present their draft papers at our conferences; and we also accept submissions from scholars who cannot attend the conferences.

This first issue of the Journal contains articles that were presented at the conference "Critical Approaches to Romani Studies" held in May 2017 at CEU, and consists of three sections: articles, book reviews, arts and culture. The first three articles deal with knowledge production on Roma. Anna Mirga-Kruszelnicka discusses the role of Romani Scholars; Ioanida Costache writes on Identity Politics, Universality, Otherness, and (New) Romani Subjectivity; Jan Selling assesses the Historical Irresponsibility of the Gypsy Lore Society. Felix B. Chang discusses the lessons of federalism and civil rights in the United States for "Roma integration". Verena Meier studies the role of $19^{\text {th }}$ and early $20^{\text {th }}$ century German Protestant missions in the Othering of Roma and Sinti.

In the book review section, Andzrej Mirga reviews Mihai Surdu's recent publication Those Who Count, and Jekatyerina Dunajeva reviews bell hooks' classic Talking Back: Thinking Feminist, Thinking Black. In addition to publishing reviews of recent Roma-focused texts, the Journal actively solicits reviews of pioneering works from critical race studies, gender and sexuality studies, critical policy studies, diaspora studies, colonial studies, postcolonial studies, and studies of decolonization. Furthermore, the Journal welcomes critical reviews of documents that inform Roma inclusion policies.

Finally, the Journal includes a section on Arts and Culture which is edited in close cooperation with the recently founded European Roma Institute for Arts and Culture (ERIAC). This section comprises articles on Roma representation, self-representation, and cultural appropriation. The journal solicits reviews of both Romani cultural products and artistic works on Roma. The first issue includes an essay on Romani Design by Ágota Szilágyi-Kispista, along with Sunnie Rucker-Chang's study of African-American and Romani cinematic representations. 